\title{
Apparent Digestibility of Feedstuffs by the Marine Shrimp Penaeus vannamei BOONE
}

\author{
D. M. Akiyama, ${ }^{* 2}$ S. R. Coelho, ${ }^{* 3}$ A. L. Lawrence, ${ }^{* 1}$ \\ and E. H. Robinson*4 \\ (Received June 6, 1988)
}

\begin{abstract}
The apparent dry matter digestibility (ADMD), apparent protein digestibility (APD), and apparent amino acid digestibility (AAAD) of thirteen feedstuffs used for marine shrimp diets were determined for the marine shrimp, Penaeus vannamei. The feedstuffs evaluated were casein, corn starch, gelatin, soy protein, wheat gluten, fish meal, rice bran, shrimp meal, soybean meal, squid meal, cellulose, chitin, and diatomaceous sand. Each feedstuff comprised $88 \%$ of the experimental diets. The ADMD values ranged from $91.4 \%$ to $-21.4 \%$. The purified feedstuffs were more efficiently digested than the practical feedstuffs. The dietary fillers (cellulose, chitin, and diatomaceous sand) were either poorly digested or not digested.

The APD values ranged from $99.1 \%$ to $3.0 \%$. There were no differences in APD due to animal or plant feedstuff origin. The AAAD were determined for arginine, lysine, leucine, isoleucine, threonine, valine, histidine, phenylalanine, glutamate, aspartate, glycine, proline, serine, tryrosine, and alanine. The digestibility trends observed for APD were similar for AAAD. The high AAAD for chitin suggested that the low APD was due to the low digestibility of the amine fraction of the chitin structure and not a low protein digestibility. Arginine, lysine, and glutamate were most efficiently digested, while alanine had the lowest apparent digestibility value.
\end{abstract}

The development of an adequate diet is essential for the commercial rearing of penaeid shrimp. Diets have been generally evaluated in terms of growth with little attention to the digestibility of compounded diets or individual feedstuffs by shrimp. Digestibility trials evaluate the nutritional value of a feedstuff which provides important information that supplements growth measurements.

Direct measurement of the apparent digestibility of diets by shrimp is difficult because of problems in measuring total ingestion and egestion in an aquatic environment. As a result, an indirect method employing chromic oxide as an inert marker has been utilized by most investigators. The apparent digestibility of dry matter, ${ }^{1-8)}$ protein, ${ }^{4-8)}$ carbohydrate, ${ }^{8,8)}$ lipid, ${ }^{97}$ mineral, ${ }^{8)}$ amino acids, ${ }^{10)}$ and sterols ${ }^{11)}$ have been estimated for shrimp with this method.

To evaluate feedstuffs commonly used in shrimp diets, the apparent dry matter digestibility
(ADMA), apparent protein digestibility (APD), and apparent amino acid digestibility (AAAD) were determined for these feedstuffs for $P$. vannamei.

\section{Materials and Methods}

$P$. vannamei were tank-reared from postlarvae at the Texas A \& M University Shrimp Mariculture Project, Port Aransas, Texas. The average initial weight, which was determined 2 weeks prior to the feeding trial to avoid undue stress, was $22.3 \pm 2.4 \mathrm{~g}$. Six shrimp were stocked per $189 l$ $\left(0.34 \mathrm{~m}^{2}\right.$ bottom) fiberglass tank. These tanks were free of substrates and were maintained as part of a semi-closed $80.7 \mathrm{t}$ recirculating system. Seawater exchange rate of the total recirculating system was $10 \% /$ week and the flow rate of seawater into each experimental tank was $2 l / \mathrm{min}$. Temperature, salinity, $\mathrm{pH}$, and dissoved oxygen ranged from 25.0 to $29.2^{\circ} \mathrm{C}, 30$ to $32 \mathrm{ppt}, 8.2$ to

*1 Texas A \& M University, Shrimp Mariculture Project, Texas Agricultural Experiment Station, P. O. Drawer Q, Port Aransas, TX 78373.

*2 Present address: American Soybean Association, 541 Orchard Road, $¥ 11-03$ Liat Towers, Singapore 0923.

*3 Present address: EMPARN-C.P. 836, Natal, RN, CEP: 59000, Brazil.

*4 Present address: Mississippi State University, Delta Branch. 
8.3 , and 6.2 to $7.9 \mathrm{ppm}$, respectively. Ammonia, nitrite, and nitrate averaged $.02 \pm .02 \mathrm{mg} / l, .03 \pm$ $.01 \mathrm{mg} / l$, and $1.36 \pm .06 \mathrm{mg} / l$, respectively. Three hundred watt incandescent overhead lamps provided lighting on a $12 \mathrm{~h}$ daylight schedule.

Thirteen diets were tested. Each diet contained $88 \%$ of the tested feedstuff, $4 \%$ attractant, $7 \%$ binder mixture, and $1 \%$ chromic oxide (Table 1 ). The feedstuffs tested were casein, cellulose, chitin, corn starch, diatomaceous sand, fish meal, gelatin, rice bran, shrimp meal, soy protein, soybean meal, squid meal, and wheat gluten. The pre-

Table 1. Composition of experimental diets*1

\begin{tabular}{lc}
\hline \multicolumn{1}{c}{ Ingredient } & Percentage \\
\hline Binder mixture*2 & 7 \\
Attractant $^{* 3}$ & 4 \\
Feedstuff $^{* 4}$ & 88 \\
Chromic oxide & 1 \\
\hline
\end{tabular}

*1 Percent dry matter basis.

*2 $4.5 \%$ alginate and $2.5 \%$ sodium hexametaphosphate.

*8 Squid puree : blended frozen squid with $20 \%$ deionized water.

* Feedstuffs tested:

casein, vitamin free: ICN, lot $\$ 14423$

cellulose: ICN, lot $\$ 15138$

chitin: Sigma, lot $\$ 12 \mathrm{~F}-7060$

corn starch: ICN, lot $\# 11205$

diatomaceous sand: Fischer Scientific, lot $\$ 735023$

fish meal, menhaden: Zapata-Haynie Co., Houston, TX gelatin: ICN, lot \#14392

rice bran, defatted: Rivina Foods Inc., Houston, TX shrimp meal: Blum and Bergeron Co, Houma, LA soy protein: ICN, lot \#14259

soybean meal: Continental Grains, Inc., Houston, TX

squid meal: laboratory prepared as described by Lee et al.28) wheat gluten: ICN, lot \$13542 paration of these diets was similar to Meyers. ${ }^{12}$ All diets were cold extruded with a Hobart Kitchen Aid noodle maker with a $2 \mathrm{~mm}$ orifice die. All diets were water stable for a minimum of $1 \mathrm{~h}$.

Shrimp were placed into the tanks 2 weeks prior to the start of the feeding trial as an acclimation period. During this period they were fed a complete $40 \%$ protein maintenance diet. The shrimp were fasted for 1 day then fed the experimental diets with fecal collection the following 2 days. The shrimp were then fed the maintenance diet for 2 days and the above procedure was repeated. These two sets of 2 day fecal collection periods were pooled and represented one replicate. Each replicate is a composite of fecal material from 24 shrimp ( 6 shrimp/tank $\times 4$ days of fecal collection). After an additional 4 days on the maintenance diet, another replicate was collected. A total of three replicates were collected for each experimental diet.

At the start of each fecal collection day, tanks were randomly assigned an experimental diet therefore, shrimp were possibly fed different ex-perimental diets on any given day. This was done to maximize the number of shrimp which contributed fecal material to each replicate and to compensate for the nutritionally imbalanced diets. The shrimp were fed $a b$ libitum. Feeding and fecal collection were continuous for $6 \mathrm{~h}$. The experimental diets were replaced every $2 \mathrm{~h}$ and fecal material was collected every hour. The rate of passage in shrimp is diet dependent, how-

Table 2. Chemical composition of the experimental diets*1

\begin{tabular}{|c|c|c|c|c|c|}
\hline $\begin{array}{l}\text { Major feedstuff } \\
\text { in diet }\end{array}$ & $\begin{array}{c}\text { Protein } \\
(\mathrm{N} \times 6.25)\end{array}$ & $\begin{array}{l}\text { Ether } \\
\text { extract }\end{array}$ & $\begin{array}{l}\text { Crude } \\
\text { fiber }\end{array}$ & Ash & $\begin{array}{c}\text { Nitrogen } \\
\text { free extract }\end{array}$ \\
\hline \multicolumn{6}{|l|}{ Purified feedstuffs } \\
\hline Casein & 88.0 & 1.6 & 0.4 & 5.3 & 4.7 \\
\hline Wheat gluten & 75.9 & 14.2 & 1.1 & 5.2 & 3.6 \\
\hline Soy protein & 81.6 & 1.7 & 0.7 & 6.7 & 9.3 \\
\hline Gelatin & 91.2 & 0.9 & 1.5 & 4.8 & 1.6 \\
\hline Corn starch & 2.7 & 0.8 & 0.5 & 4.3 & 91.7 \\
\hline \multicolumn{6}{|l|}{ Practical feedstuffs } \\
\hline Squid meal & 72.0 & 10.9 & 7.9 & 7.7 & 1.5 \\
\hline Fish meal & 65.0 & 10.2 & 0.9 & 21.3 & 2.6 \\
\hline Shrimp meal & 43.6 & 4.5 & 10.7 & 34.5 & 6.7 \\
\hline Soybean meal & 45.5 & 2.6 & 6.2 & 10.9 & 34.8 \\
\hline Rice bran & 19.2 & 4.8 & 9.3 & 14.8 & 51.9 \\
\hline \multicolumn{6}{|l|}{ Dietary fillers } \\
\hline Diatomaceous sand & 2.5 & 1.1 & 1.1 & 91.9 & 3.4 \\
\hline Chitin & $34.2 * 2$ & 1.2 & 71.9 & 14.4 & 1.2 \\
\hline Cellulose & 2.5 & 1.1 & 87.0 & 4.6 & 4.8 \\
\hline
\end{tabular}

*1 Percent dry matter basis.

*2 Over estimated value due to glucosamine content. 


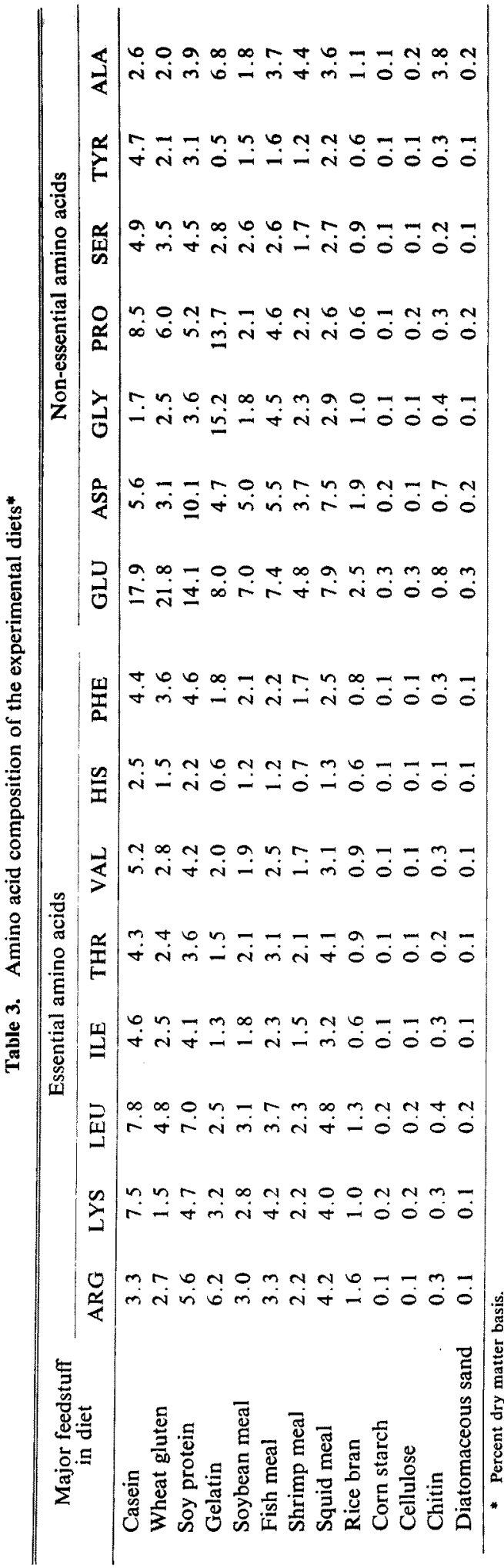

ever it was observed that complete passage of these experimental diets occured within $2 \mathrm{~h}$ and feces were collected for $2 \mathrm{~h}$ after the last feeding. No shrimp were observed consuming fecal material. The first colored feces to appear were discarded to eliminate any influence of previously ingested food. Feces were collected from the experimental tanks by siphoning into a plastic sieve. Since shrimp feces are encased in a membrane, feces were rinsed with the deionized water to separate out the uneaten food and salt water. Feces were then frozen at $-10^{\circ} \mathrm{C}$.

After all replicates were completed, samples were lyophilized using a Labconco freeze dryer model $\$ 18$. The samples were analyzed for chromic oxide by the method of McGinnis and Kasting. ${ }^{13)}$ Nitrogen was determined by a microKjeldahl method described by Ma and Zuazago. ${ }^{14)}$ Protein was estimated by $N \times 6.25$. Other proximate analyses were determined by the methods of AOAC. ${ }^{15)}$ All chemical determinations were done in triplicate and reported on a dry matter basis (Table 2).

For the amino acid determinations, samples were hydrolyzed in $6 \mathrm{~N} \mathrm{HCl}$ for $24 \mathrm{~h}$ at $104^{\circ} \mathrm{C}$. These samples were evaporated to dryness and mixed with pH 2.2 lithium citrate buffer. The solutions were then analyzed with a LKB amino acid analyzer model $\sharp 4400$. The concentrations of methionine, cysteine, and tryptophan were not determined. All determinations are reported on a dry matter basis (Table 3 ).

The ADMD, APD, and AAAD were calculated by the equation:

$$
\begin{gathered}
100\left[100-\left(\frac{\% \text { nutrient in feces }}{\% \text { nutrient in feed }}\right.\right. \\
\left.\left.\times \frac{\% \mathrm{Cr}_{2} \mathrm{O}_{3} \text { in feed }}{\% \mathrm{Cr}_{2} \mathrm{O}_{3} \text { in feces }}\right)\right]
\end{gathered}
$$

The data was statistically analyzed by the procedures developed by SAS. ${ }^{10)}$ Analysis of variance and Waller-Duncan's multiple range test were used to compare the ADMD, APD, and AAAD between diets. In the comparison for AAAD, the diets formulated with the purified and practical feedstuffs were evaluated separately from the diets in which protein was provided solely from the squid attractant. The chitin based diet was also analysed with this latter group because only a minimum amount of amino acids is believed to be contributed by the chitin. 


\section{Results and Discussion}

Digestibility of a feed is an important parameter to consider in determining the utilization of a feed. Digestibility values are affected differently by the associative effects of the constituents of the diet. Thus the digestibility value for the diet may not be the average of the values of each constituent. ${ }^{17)}$ To better evaluate the digestibility of feedstuffs, a feed should be compounded solely of the feedstuff being evaluated to eliminate the possibility of an associative effect. The addition of the binder and attractant in these experimental diets were necessary to standardize each diet. The utilization of $88 \%$ of each feedstuff in the diets was an attempt to minimize the possibility of associative effects of varying feedstuffs.

The diet consisting of $88 \%$ diatomaceous sand was an attempt to estimate the ADMD, APD, and AAAD of the binder and attractant. Assuming that diatomaceous sand was undigestible, the observed ADMD, APD, and AAAD of this diet would have been used as a correction factor for the other diets. However, an unexpected negative ADMD rather than a slightly positive ADMD was observed for this diet. Because of this negative $A D M D$, it was considered inappropriate to use these values (ADMD, APD, and AAAD) as a correction factor for the other diets.

Chromic oxide was reported to be an inappropriate indirect digestibility marker in the American lobster. ${ }^{18,18)}$ It was reported that chromic oxide was selectively passed before the waste products of digestion and was not homogeneously mixed in the fecal material. In this study, the initial fecal material was discarded. However, this resulted in only a small loss of fecal material because of relative large amount collected due to the rapid rate of passage observed in shrimp. The initial discard of fecal material may be a possible source of error. The low standard deviation between replicates suggests reproducibility of the observed results and a homogeneous mix of chromic oxide and the waste products of digestion. Therefore, chromic oxide appears to be an appropriate digestibility marker for penaeid shrimp. However, the utilization of an inert marker indirectly measures digestibility and these values represent digestibility relative to the other feedstuffs.

The ADMD of the experimental diets ranged from $91.4 \%$ to $-21.4 \%$ (Table 4 ). These ADMD values were in general lower than those reported for prepared dry diets fed to a shrimp by other investigators. ${ }^{4,6,7)}$ A major difference is that the diets used in this study were nutritionally incomplete whereas the previously reported ADMD values were for complete diets. The lower ADMD values may also be due to differences in species and size of shrimp, environmental conditions, and experimental conditions.

The ADMD of the diets containing the purified feedstuffs high in protein: casein, gelatin, soy pro-

Table 4. Apparent dry matter digestibility and apparent protein digestibility of experimental diets by the marine shrimp, Penaeus vannamei*1

\begin{tabular}{ccc}
\hline $\begin{array}{c}\text { Major feedstuff } \\
\text { in diet }\end{array}$ & $\begin{array}{c}\text { Apparent dry matter } \\
\text { digestibility }\end{array}$ & $\begin{array}{c}\text { Apparent protein } \\
\text { digestibility }\end{array}$ \\
\hline Purified feedstuffs & $91.4 \pm 0.1^{\mathrm{s}}$ & $99.1 \pm 0.1^{\mathrm{a}}$ \\
Casein & $85.4 \pm 0.4^{\mathrm{b}}$ & $98.0 \pm 0.4^{\mathrm{a}}$ \\
Wheat gluten & $84.1 \pm 0.8^{\mathrm{b}}$ & $96.4^{\mathrm{b}} \pm 0.4^{\mathrm{a}}$ \\
Soy protein & $85.2 \pm 1.2^{\mathrm{b}}$ & $97.3 \pm 0.5^{\mathrm{a}}$ \\
Gelatin & $68.3 \pm 1.6^{\mathrm{b}}$ & $81.1 \pm 1.1^{\mathrm{c}, * 2}$ \\
Corn starch & & $79.7 \pm 1.7^{\mathrm{c}, \mathrm{a}}$ \\
Practical feedstuffs & $68.9 \pm 1.0^{\mathrm{c}}$ & $80.7 \pm 1.7^{\mathrm{e}}$ \\
Squid meal & $64.3 \pm 1.4^{\mathrm{d}}$ & $74.6 \pm 1.6^{\mathrm{e}}$ \\
Fish meal & $56.8 \pm 2.0^{\mathrm{e}}$ & $89.9 \pm 0.9^{\mathrm{b}}$ \\
Shrimp meal & $55.9 \pm 1.4^{\mathrm{e}}$ & $76.4 \pm 0.8^{\mathrm{d}, \mathrm{o}}$ \\
Soybean meal & $40.0 \pm 1.5^{\mathrm{f}}$ & \\
Rice bran & & $51.0 \pm 9.5^{\mathrm{g}, * 2}$ \\
Dietary fillers & $-5.8 \pm 0.6^{\mathrm{g}}$ & $3.0 \pm 0.6^{\mathrm{h}}$ \\
Diatomaceous sand & $-15.6 \pm 1.3^{\mathrm{b}}$ & $65.0 \pm 0.2^{\mathrm{f}, * 2}$ \\
Chitin & $-21.4 \pm 5.4^{\mathrm{l}}$ & \\
Cellulose &
\end{tabular}

*1 Values are averages for three replicates (24 shrimp/replicate) \pm standard deviations.

*2 Based solely on protein from squid attractant.

$a, b, c, d, e, f, b, h, d$ Means in the same column with different superscripts differ $(P<0.05)$. 
tein, and wheat gluten were greater than the ADMD value of the high carbohydrate diet containing corn starch. This suggests that proteins are more efficiently digested than carbohydrates. This contention has been previously reported. $\left.{ }^{8}, 20\right)$

The diets containing cellulose, chitin, and diatomaceous sand had negative ADMD values (Table 4). The negative ADMD for the cellulose and chitin diets were unexpected because cellulase and chitinase have been reported in shrimp..$^{21-24)}$ Negative ADMD values represent endogenous losses by the animal from processes such an enzymatic secretion, sloughing of gut epithelial cells, formation of the chitinous peritrophic membrane, and the secretion of other lubricative substances. Lee ${ }^{1)}$ reported a similar negative ADMD for a $2.06 \%$ protein diet formulated with $86 \%$ dextrin. Another explanation of these negative ADMD values may be due to the leaching of chromic oxide of the feed before consumption or from the fecal material. However, feeds were never in seawater for longer than two hours before being replaced and fecal material were collected within an hour of defecation. Coelho ${ }^{2)}$ and Fenuccis ${ }^{8)}$ observed that for these exposure times to the seawater, leaching of chromic oxide was negligible. Consequently, the data suggest that there is little to no digestibility of cellulose, chitin, and diatomaceous sand by $P$. vannamei.

The ADMD of the diets containing purified feedstuffs: casein, corn starch, gelatin, soy protein, and wheat gluten were higher than the diets containing practical feedstuffs: fish meal, rice bran, shrimp meal, soybean meal, and squid meal. Forster and Gabbott ${ }^{6)}$ working with Penaeus serratus observed similar results.

The APD of the experimental diets ranged from $99.1 \%$ to $3.0 \%$ (Table 4 ). These APD values are similar to those reported by other investigators. ${ }^{8,8,20)}$ The results of this study indicated that APD was not influenced by animal or plant feedstuff origin. For the experimental diets containing practical feedstuffs, soybean meal had a higher APD than fish meal, squid meal, rice bran, and shrimp meal (Table 4). There were no differences between squid meal and rice bran and between rice bran and shrimp meal. For the experimental diets containing purified feedstuffs, there were no differences between casein, wheat gluten, gelatin, and soy protein (Table 4). This digestibility similarity has been reported previously. ${ }^{5,20,25)}$ Whereas, Nose, ${ }^{4}$ Forster and Gabbott, ${ }^{8)}$ and Fenucci et al. ${ }^{8)}$ working with Penaeus japonicus, Palaemon serratus and Pandalus platy- ceros, and Penaeus stylirostris respectively, reported that protein from animal origins are better digested than protein from plant origins. These conflicting observations concerning APD are possibly related to species examined, ingredient quality, and diet composition. The AAAD values further support the contention that feedstuff origin has no effect on protein digestibility since similar trends, as discussed with APD, were observed in the AAAD (Table 5).

The ADMD of the purified feedstuffs were observed as being more efficently digested compared to the practical feedstuffs. This difference was also observed in the APD and AAAD. This indicates that proteins are more readily digested in the purified form. This is further emphasized by the comparison of the purified and practical forms of soybean protein. The soy protein had a higher APD than soybean meal. This higher digestibility was also observed for all amino acids measured. This suggests that the other chemical components (lipid, carbohydrates, etc.) of soybean meal may have decreased APD and AAAD.

The low APD of the chitin diet is deceiving. Chitin is a polymer of $\mathrm{N}$-acetyl-D-glucosamine linked in a B-1-4 glucosidic bond similar to cellulose. This amine fraction would elevate the estimated protein values $(\mathrm{N} \times 6.25)$ of the diet. Assuming that cellulose and chitin are not digestible, the APD values should be similar because both are fibers and contain the same type and quantity of protein due to the squid which was added as the attractant. The APD of chitin was lower than cellulose. However, similar digestibilities were suggested by the AAAD values (Table 6). Of the 15 amino acids studied, only 2 were observed to have different digestibility values.

Phenylalanine had a lower apparent digestibility whereas aspartate had a higher digestibility in the chitin diet compared to the cellulose diet. Protein has also been reported to be linked to chitin at a ratio of chitin to protein of $1: 1$ to $20: 1 .{ }^{28)}$ The chitin bound protein was indicated by the amino acid composition of the chitin diet which was $6 \%$ to $7 \%$ higher than the cellulose diet. The differentiation between the digestibility of amino acids from the squid attractant and chitin is difficult. Therefore, the digestibility of the chitin bound amino acid is unknown.

The APD value for shrimp meal was lower than fish meal and squid meal (Table 4). However, comparing the AAAD there seem to be no difference between these feedstuffs (Table 5). The shrimp meal diet contained $10.7 \%$ crude fiber 
Table 5. Apparent amino acid digestibility of the experimental diets by the marine shrimp, Penaeus vannamei*

\begin{tabular}{|c|c|c|c|c|c|c|c|c|c|c|c|c|c|c|c|}
\hline \multirow{2}{*}{$\begin{array}{l}\text { Major feedstuff } \\
\text { in diet }\end{array}$} & \multicolumn{8}{|c|}{ Essential amino acids } & \multicolumn{7}{|c|}{ Non-essential amino acids } \\
\hline & ARG & LYS & LEU & ILE & THR & VAL & HIS & PHE & GLU & ASP & GLY & PRO & SER & TYR & ALA \\
\hline Casein & $\begin{array}{l}99.2^{\mathrm{a}} \\
(0.2)\end{array}$ & $\begin{array}{l}99.5^{\mathrm{a}} \\
(0.1)\end{array}$ & $\begin{array}{l}99.5^{\mathrm{a}} \\
(0.1)\end{array}$ & $\begin{array}{r}99.4^{\mathrm{a}} \\
(0.1)\end{array}$ & $\begin{array}{l}99.1^{\mathrm{a}} \\
(0.2)\end{array}$ & $\begin{array}{l}99.4^{\mathrm{a}} \\
(0.1)\end{array}$ & $\begin{array}{l}99.3^{\mathrm{a}} \\
(0.2)\end{array}$ & $\begin{array}{l}99.4^{\mathrm{a}} \\
(0.2)\end{array}$ & $\begin{array}{r}99.5^{\mathrm{a}} \\
(0.1)\end{array}$ & $\begin{array}{r}98.9^{a} \\
(0.2)\end{array}$ & $\begin{array}{r}98.4^{\mathrm{a}} \\
(0.1)\end{array}$ & $\begin{array}{l}99.3^{\mathrm{a}} \\
(0.1)\end{array}$ & $\begin{array}{r}99.2^{\mathrm{a}} \\
(0.1)\end{array}$ & $\begin{array}{l}99.5^{\mathrm{a}} \\
(0.1)\end{array}$ & $\begin{array}{l}97.9^{\mathrm{a}} \\
(0.1)^{2}\end{array}$ \\
\hline Wheat gluten & $\begin{array}{l}98.1^{\mathrm{a}} \\
(0.4)\end{array}$ & $\begin{array}{l}96.7^{\mathrm{a}} \\
(0.6)\end{array}$ & $\begin{array}{l}98.5^{\mathrm{ab}} \\
(0.4)\end{array}$ & $\begin{array}{l}98.3^{\mathrm{Eb}} \\
(0.5)\end{array}$ & $\begin{array}{l}97.2^{\mathrm{ab}} \\
(0.2)\end{array}$ & $\begin{array}{l}98.1 \mathrm{ab} \\
(0.4)\end{array}$ & $\begin{array}{r}98.1^{\mathrm{a}} \\
(0.3)\end{array}$ & $\begin{array}{l}98.7^{\mathrm{ab}} \\
(0.2)\end{array}$ & $\begin{array}{l}99.2^{8 \mathrm{~b}} \\
(0.2)\end{array}$ & $\begin{array}{l}96.0^{\mathrm{a}} \\
(0.7)\end{array}$ & $\begin{array}{l}97.3^{\mathrm{ab}} \\
(0.5)\end{array}$ & $\begin{array}{l}99.1^{\mathrm{a}} \\
(0.3)\end{array}$ & $\begin{array}{l}98.0^{\mathrm{ab}} \\
(0.2)\end{array}$ & $\begin{array}{l}98.3^{\mathrm{a}} \\
(0.3)\end{array}$ & $\begin{array}{l}94.1^{\mathrm{a}} \\
(2.1)\end{array}$ \\
\hline Soy protein & $\begin{array}{l}97.5^{\mathrm{a}} \\
(0 .)^{2}\end{array}$ & $\begin{array}{l}97.5^{\mathrm{a}} \\
(0.6)\end{array}$ & $\begin{array}{l}96.7^{\mathrm{ab}} \\
(0.4)\end{array}$ & $\begin{array}{l}96.8^{b c} \\
(0.8)\end{array}$ & $\begin{array}{l}95.3^{\mathrm{b}} \\
(0.7)\end{array}$ & $\begin{array}{l}96.4^{\mathrm{ab}} \\
(0.7)\end{array}$ & $\begin{array}{l}96.7^{\mathrm{ab}} \\
(0.5)\end{array}$ & $\begin{array}{l}96.6^{\mathrm{ab}} \\
(0.6)\end{array}$ & $\begin{array}{l}97.7^{\mathrm{bc}} \\
(0.4)\end{array}$ & $\begin{array}{r}97.2^{\mathrm{a}} \\
(0.4)\end{array}$ & $\begin{array}{l}95.8^{\mathrm{b}} \\
(0.4)\end{array}$ & $\begin{array}{l}97.2^{\mathrm{a}} \\
(0.5)\end{array}$ & $\begin{array}{l}96.4^{\mathrm{b}} \\
(0.5)\end{array}$ & $\begin{array}{l}97.1^{\mathrm{a}} \\
(0.6)\end{array}$ & $\begin{array}{l}94.1^{\circ} \\
(0.5)\end{array}$ \\
\hline Gelatin & $\begin{array}{l}98.4^{\mathrm{a}} \\
(0.9)\end{array}$ & $\begin{array}{l}96.9^{\mathrm{s}} \\
(0.7)\end{array}$ & $\begin{array}{c}96.2^{\mathrm{b}} \\
(0.8)\end{array}$ & $\begin{array}{l}95.8^{\circ} \\
(1.0)\end{array}$ & $\begin{array}{l}94.5^{\mathrm{b}} \\
(0.4)\end{array}$ & $\begin{array}{l}96.1^{\mathrm{b}} \\
\left(0.7^{2}\right.\end{array}$ & $\begin{array}{l}93.6^{b} \\
(1.7)\end{array}$ & $\begin{array}{l}96.3^{\mathrm{b}} \\
(0.9)\end{array}$ & $\begin{array}{l}97.0^{\mathrm{c}} \\
(0.4)\end{array}$ & $\begin{array}{l}95.9^{\mathrm{ab}} \\
(0.1)\end{array}$ & $\begin{array}{l}98.1^{\mathrm{ab}} \\
(0.4)\end{array}$ & $\begin{array}{l}98.4^{\mathrm{a}} \\
(0.3)\end{array}$ & $\begin{array}{r}96.2^{\mathrm{b}} \\
(0.4)\end{array}$ & $\begin{array}{l}92.2^{\mathrm{b}} \\
(3.4)\end{array}$ & $\begin{array}{l}97.0^{\mathrm{B}} \\
(0.5)\end{array}$ \\
\hline Soybean meal & $\begin{array}{l}91.4^{b} \\
(2.9)\end{array}$ & $\begin{array}{l}91.5^{b} \\
(2.2)\end{array}$ & $\begin{array}{r}88.4^{\mathrm{c}} \\
(1.9)\end{array}$ & $\begin{array}{l}90.2^{\mathrm{d}} \\
(2.0)\end{array}$ & $\begin{array}{l}89.3^{c} \\
(1.5)\end{array}$ & $\begin{array}{l}87.9^{\circ} \\
(2.4)\end{array}$ & $\begin{array}{l}86.3^{\mathrm{c}} \\
(4.8)\end{array}$ & $\begin{array}{l}89.6^{\mathrm{c}} \\
(1.8)\end{array}$ & $\begin{array}{l}91.9^{\mathrm{d}} \\
(1.3)\end{array}$ & $\begin{array}{l}92.2^{b} \\
(1.3)\end{array}$ & $\begin{array}{l}87.0^{\mathrm{c}} \\
(1.6)\end{array}$ & $\begin{array}{l}89.1^{b} \\
(1.4)\end{array}$ & $\begin{array}{l}88.5^{\mathrm{c}} \\
(2.8)\end{array}$ & $\begin{array}{l}91.1^{\mathrm{b}} \\
(1.6)\end{array}$ & $\begin{array}{l}85.9^{\mathrm{c}} \\
(1.7)\end{array}$ \\
\hline Fish meal & $\begin{array}{l}81.0^{\mathrm{d}} \\
(1.3)\end{array}$ & $\begin{array}{l}83.1^{\mathrm{ed}} \\
(2.6)\end{array}$ & $\begin{array}{r}80.7^{\mathrm{a}} \\
(2.6)\end{array}$ & $\begin{array}{l}80.4^{\circ} \\
(1.8)\end{array}$ & $\begin{array}{l}80.6^{\mathrm{d}} \\
(2.7)\end{array}$ & $\begin{array}{l}79.4^{\mathrm{d}} \\
(1.4)\end{array}$ & $\begin{array}{l}79.0^{\circ} \\
(0.8)\end{array}$ & $\begin{array}{l}79.1^{\mathrm{d}} \\
(0.8)\end{array}$ & $\begin{array}{l}82.4^{e} \\
(1.8)\end{array}$ & $\begin{array}{l}80.6^{\mathrm{cd} d} \\
(2.2)\end{array}$ & $\begin{array}{l}82.2^{d} \\
(0.9)\end{array}$ & $\begin{array}{l}84.1^{\mathrm{c}} \\
(0.7)\end{array}$ & $\begin{array}{l}81.6^{d} \\
(1.6)\end{array}$ & $\begin{array}{l}78.4^{\mathrm{c}} \\
(1.1)^{-}\end{array}$ & $\begin{array}{l}81.4^{\mathrm{d}} \\
(0.9)\end{array}$ \\
\hline Shrimp meal & $\begin{array}{l}81.8^{\mathrm{d}} \\
(2.9)\end{array}$ & $\begin{array}{l}85.7^{\mathrm{c}} \\
(2.8)\end{array}$ & $\begin{array}{l}82.1^{\mathrm{d}} \\
(2.7)\end{array}$ & $\begin{array}{l}81.6^{\circ} \\
\left(2.9^{\circ}\right)\end{array}$ & $\begin{array}{l}83.7^{\mathrm{d}} \\
(3.8)\end{array}$ & $\begin{array}{l}79.0^{\mathrm{d} \theta} \\
(3.2)\end{array}$ & $\begin{array}{l}75.4^{\mathrm{r}} \\
(3.2)\end{array}$ & $\begin{array}{l}75.6^{e} \\
(3.1)\end{array}$ & $\begin{array}{r}82.0^{\circ} \\
(1.5)\end{array}$ & $\begin{array}{l}78.6^{\mathrm{de}} \\
(4.2)\end{array}$ & $\begin{array}{l}80.3^{\mathrm{d}} \\
(3.7)\end{array}$ & $\begin{array}{l}78.8^{d} \\
(3.4)\end{array}$ & $\begin{array}{l}78.0^{\mathrm{e}} \\
(2.9)\end{array}$ & $\begin{array}{l}76.7^{\mathrm{c}} \\
(3.1)\end{array}$ & $\begin{array}{l}55.4^{\mathrm{g}} \\
(0.8)\end{array}$ \\
\hline Squid meal & $\begin{array}{l}79.4^{\mathrm{d}} \\
(0.6)\end{array}$ & $\begin{array}{l}78.6^{\circ} \\
(1.1)\end{array}$ & $\begin{array}{l}79.4^{\mathrm{d}} \\
(1.4)\end{array}$ & $\begin{array}{l}77.2^{6} \\
(1.6)\end{array}$ & $\begin{array}{l}79.7^{\circ} \\
(1.9)\end{array}$ & $\begin{array}{l}79.3^{\mathrm{d}} \\
(2.6)\end{array}$ & $\begin{array}{l}73.6^{\mathrm{e}} \\
(0.9)\end{array}$ & $\begin{array}{l}74.1^{\circ} \\
(0.9)\end{array}$ & $\begin{array}{r}82.2^{\circ} \\
(1.0)\end{array}$ & $\begin{array}{l}83.2^{\mathrm{c}} \\
(4.5)\end{array}$ & $\begin{array}{l}80.4^{4} \\
(0.7)\end{array}$ & $\begin{array}{l}78.5^{\mathrm{d}} \\
(0.5)\end{array}$ & $\begin{array}{l}77.2^{\circ} \\
(1.4)\end{array}$ & $\begin{array}{l}73.5^{\mathrm{d}} \\
(0.1)\end{array}$ & $\begin{array}{l}77.0^{\circ} \\
(1.3)\end{array}$ \\
\hline Rice bran & $\begin{array}{l}85.1^{\mathrm{c}} \\
(2.2)\end{array}$ & $\begin{array}{l}81.0^{\mathrm{d} \theta} \\
(5.2)\end{array}$ & $\begin{array}{r}74.9^{\circ} \\
(3.5)\end{array}$ & $\begin{array}{l}73.4^{8} \\
(1.3)\end{array}$ & $\begin{array}{l}73.2^{\mathrm{f}} \\
(4.1)\end{array}$ & $\begin{array}{l}75.9^{\circ} \\
(3.6)\end{array}$ & $\begin{array}{l}82.6^{\mathrm{d}} \\
(2.5)\end{array}$ & $\begin{array}{l}74.9^{\circ} \\
(3.8)\end{array}$ & $\begin{array}{l}79.5^{\mathrm{f}} \\
(2.0)\end{array}$ & $\begin{array}{l}75.5^{\circ} \\
(2.9)\end{array}$ & $\begin{array}{l}75.9^{\circ} \\
(2.5)\end{array}$ & $\begin{array}{l}68.7^{\mathrm{e}} \\
(6.5)\end{array}$ & $\begin{array}{l}72.7^{5} \\
(3.0)\end{array}$ & $\begin{array}{l}75.8^{\mathrm{cd}} \\
(1.5)\end{array}$ & $\begin{array}{l}71.0^{\mathrm{r}} \\
(2.0)\end{array}$ \\
\hline
\end{tabular}

- Values are averages for three replicates [24 shrimp/replicate]+standard deviation in [

B,b.e,d,e,f,g Means in the same column with different superseripts differ $[\mathrm{P}<0.05]$

Table 6. Apparent amino acid digestibility of the experimental diets containing protein solely from the squid attractant by the marine shrimp, Penaeus vannamei ${ }^{* 1}$

\begin{tabular}{|c|c|c|c|c|c|c|c|c|c|c|c|c|c|c|c|}
\hline \multirow{2}{*}{$\begin{array}{c}\text { Major feedstuff } \\
\text { in diet }\end{array}$} & \multicolumn{8}{|c|}{ Essential amino acids } & \multicolumn{7}{|c|}{ Non-essential amino acids } \\
\hline & ARG & LYS & LEU & ILE & THR & VAL & HIS & PHE & GLU & ASP & GLY & PRO & SER & TYR & ALA \\
\hline Corn starch & $\begin{array}{r}85.5^{\mathrm{a}} \\
(3.6)\end{array}$ & $\begin{array}{l}86.7^{\mathrm{a}} \\
(2.7)\end{array}$ & $\begin{array}{l}85.8^{\mathrm{a}} \\
(0.5)\end{array}$ & $\begin{array}{l}84.7^{\mathrm{a}} \\
(1.1)\end{array}$ & $\begin{array}{l}70.5^{\mathrm{a}} \\
(6.5)\end{array}$ & $\begin{array}{l}80.9^{a} \\
(4.3)\end{array}$ & $\begin{array}{l}77.0^{\mathrm{a}} \\
(6.3)\end{array}$ & $\begin{array}{l}81.3^{\mathrm{a}} \\
(1.4)\end{array}$ & $\begin{array}{l}80.4^{\mathrm{a}} \\
(3.6)\end{array}$ & $\begin{array}{l}73.9^{\mathrm{a}} \\
(10.1)\end{array}$ & $\begin{array}{l}74.5^{\mathrm{a}} \\
(11.3)\end{array}$ & $\begin{array}{l}77.6^{\mathrm{a}} \\
(5.2)\end{array}$ & $\begin{array}{l}68.5^{\mathrm{a}} \\
(5.8)\end{array}$ & $\begin{array}{l}84.2^{\mathrm{s}} \\
(0.8)\end{array}$ & $\begin{array}{l}33.6^{\mathrm{a}} \\
(9.1)\end{array}$ \\
\hline Cellulose & $\begin{array}{l}55.7^{\mathrm{ab}} \\
(7.7)\end{array}$ & $\begin{array}{l}72.0^{\mathrm{ab}} \\
(4.7)\end{array}$ & $\begin{array}{l}64.2^{\mathrm{ab}} \\
(10.4)\end{array}$ & $\begin{array}{r}67.3^{\mathrm{b}} \\
(8.0)\end{array}$ & $\begin{array}{l}44.7^{b} \\
(10.7)\end{array}$ & $\begin{array}{r}46.9^{\mathrm{b}} \\
(9.3)\end{array}$ & $\begin{array}{l}38.1^{\mathrm{ab}} \\
(33.2)\end{array}$ & $\begin{array}{l}43.6^{b} \\
(20.2)\end{array}$ & $\begin{array}{r}53.7^{b} \\
(11.9)\end{array}$ & $\begin{array}{l}6.2^{b} \\
(2.1)\end{array}$ & $\begin{array}{r}44.8^{b} \\
(4.2)\end{array}$ & $\begin{array}{r}28.8^{\mathrm{b}} \\
(4.9)\end{array}$ & $\begin{array}{c}36.9^{\mathrm{a}} \\
(18.6)\end{array}$ & $\begin{array}{l}52.2^{\mathrm{b}} \\
(10.9)\end{array}$ & $\begin{array}{r}15.8^{\mathrm{b}} \\
(8.0)\end{array}$ \\
\hline Chitin*2 & $\begin{array}{l}61.4^{\mathrm{ab}} \\
(28.8)\end{array}$ & $\begin{array}{l}53.0^{\mathrm{be}} \\
(12.3)\end{array}$ & $\begin{array}{r}45.4^{b} \\
(20.2)\end{array}$ & $\begin{array}{l}64.8^{b} \\
(9.1)\end{array}$ & $\begin{array}{r}30.3^{b} \\
(11.1)\end{array}$ & $\begin{array}{l}60.0^{\mathrm{ab}} \\
(19.2)\end{array}$ & $\begin{array}{r}2.1^{\mathrm{b}} \\
(24.4)\end{array}$ & $\begin{array}{r}4.3^{\circ} \\
(6.6)\end{array}$ & $\begin{array}{r}63.8^{\mathrm{b}} \\
(8.9)\end{array}$ & $\begin{array}{r}56.7^{\mathrm{B}} \\
(11.3)\end{array}$ & $\begin{array}{r}28.5^{\mathrm{b}} \\
(6.2)\end{array}$ & $\begin{array}{r}37.8^{b} \\
(4.8)\end{array}$ & $\begin{array}{c}36.4^{a} \\
(20.5)\end{array}$ & $\begin{array}{r}51.3^{\mathrm{b}} \\
(8.3)\end{array}$ & $\begin{array}{l}3.6^{\circ} \\
(2.6)\end{array}$ \\
\hline $\begin{array}{l}\text { Diatomaceous } \\
\text { sand }\end{array}$ & $\begin{array}{l}41.3^{\mathrm{b}} \\
(2.5)\end{array}$ & $\begin{array}{r}38.4^{\mathrm{c}} \\
(17.3)\end{array}$ & $\begin{array}{r}55.4^{\mathrm{b}} \\
(10.2)\end{array}$ & $\begin{array}{l}42.8^{\circ} \\
(11.1)\end{array}$ & $\begin{array}{l}25.7^{\mathrm{b}} \\
(1.4)\end{array}$ & $\begin{array}{l}45.3^{b} \\
(14.9)\end{array}$ & $\begin{array}{c}40.9^{\mathrm{a} b} \\
(8.7)\end{array}$ & $\begin{array}{r}-1.2^{\mathrm{e}} \\
(4.8)\end{array}$ & $\begin{array}{r}26.5^{\mathrm{e}} \\
(8.0)\end{array}$ & $\begin{array}{l}0.9 \mathrm{~b} \\
(7.8)\end{array}$ & $\begin{array}{r}38.0^{\mathrm{b}} \\
(8.6)\end{array}$ & $\begin{array}{l}67.4^{a} \\
(20.1)\end{array}$ & $\frac{-3.2^{b}}{(21.9)}$ & $\begin{array}{l}19.3^{c} \\
(24.3)\end{array}$ & $\begin{array}{r}-176.9^{\circ} \\
(65.9)\end{array}$ \\
\hline
\end{tabular}

1 Values are averages for three replicates 
which consisted of chitin. The amine fraction in chitin would lower the estimated APD but should have little influence on the AAAD.

. The APD and AAAD values of the cellulose and diatomaceous sand diets should have been similar to the corn starch diet because the only source of protein was the squid attractant. The APD of these diets were all different (Table 4). The corn starch diet had the highest APD, followed by the cellulose and diatomaceous sand diets, respectively. Similar digestibility trends were observed for AAAD (Table 6). The cellulose and diatomaceous sand diets had negative ADMD values which were probably due to endogenous losses. These losses could have increased the excreted metabolic fecal nitrogen value and thus lowered the APD and AAAD for these diets.

It appears that the endogenous losses observed in the ADMD of the dietary fillers were not predominantly proteins or amino acids. Only the diatomaceous sand diet had negative AAAD values for 3 of the 15 amino acids. The chitin and cellulose diets had no negative AAAD values. These diets had lower ADMD values than the diatomaceous sand diet but higher APD and AAAD values. This indicates that the majority of the endogenous loss observed was not protein or amino acids and that the diatomaceous sand diet induced a higher metabolic fecal nitrogen loss compared to the cellulose and chitin diets, but the overall metabolic loss was greater with the latter 2 diets.

Alanine was poorly digested compared to other amino acids regardless of diet. This low apparent digestibility may be explained by the secretion of the chitinous peritrophic membrane surrounding the fecal material. Alanine is found at high levels in chitin and the secreted alanine would lower the apparent digestibility value. It was also observed that the more abrasive feedstuffs (cellulose, chitin, and diatomaceous sand) had low alanine digestibilities. It is possible that the secretion of the protective chitinous peritrophic membrane would be greater with abrasive materials, thus increasing the amount of secreted alanine. This increased secretion may explain the low alanine digestibility. Alanine is also found in high concentrations in body fluids of crustaceans. ${ }^{27}$ ) This indicates that it may be a metabolic product which cloud be secreted into the fecal material. A similar relationship has been suggested for glycine in shrimp. ${ }^{10)}$

Digestibility values are an important parameter to consider in diet formulations. Feedstuffs which are poorly digested would be of limited nutritional value to an animal, thus digestibility values reported in this paper supplement growth data and increases understanding of penaeid nutrition.

\section{Acknowledgements}

This work was supported in part by the James R. Dougherty, Jr. Foundation and Texas A \& M University Sea Grant College Program which is supported by the National Oceanic and Atomspheric Administration, Office of Sea Grant, U. S. Department of Commerce, under Grant No. 4 7-158-441054. The authors also acknowledge Cassia Coelho for her assistance with the biochemical analyses.

\section{References}

1) D. L. Lee: Aquaculture, 1, 1-23 (1971).

2) S. R. Coelho: M.S. Thesis, Texas A \& M University, College Station (1984).

3) L. L. Smith, P. G. Lee, A. L. Lawrence, and K. Strawn: Aquaculture, 46, 85-96 (1985).

4) T. Nose: Bull. Freshwater Fish. Res. Lab. (Tokyo), 1, 23-28 (1964).

5) D. L. Lee: China Fish. Monthly, 208, 2-4 (1970).

6) J. R. M. Forster, and P. A. Gabbott: J. Mar. Biol. Ass., U. K., 51, 943-961 (1971).

7) P. M. Colvin: Aquaculture, 7, 315-326 (1976).

8) J. L. Fenucci, A. C. Fenucci, A. L. Lawrence, and Z. P. Zein-Eldin: J. World Mariculture Soc., 13, 134-145 (1982).

9) S. Teshima, and A. Kanazawa: Nippon Suisan Gakkaishi, 49, 963-966 (1983).

10) O. Deshimaru: Nippon Suisan Gakkaishi, 42, 331-335 (1976).

11) S. Teshima, A. Kanazawa, and H. Okamoto: Nippon Suisan Gakkaishi 40, 1015-1019 (1974).

12) S. P. Meyers: J. of Aquariculture, 1, 41-46(1980).

13) A. J. McGinnis, and R. Kasting: Agric. Food Chem., 12, 259-262 (1964).

14) T.S. Ma, and G. Zuazago: Industrial and Engineering Chemistry, 14, 280-282 (1942).

15) AOAC (Association of Official Analytical Chemists). Official Methods of Analysis, 13th ed. Association of official Analytical Chemists. Washington, D. C. (1980).

16) SAS: In SAS User's Guide: Statistical Analysis System Institute, Inc., Cary, N. C. (1984).

17) B. H. Schneider, and W. P. Flatt: in "The evaluation of feeds through digestibility experiments." University of Georgia Press, Athens, GA, pp. 233 (1975).

18) D. F. Leavitt: in "Second International Conference on Aquaculture Nutrition" (ed. by G. D. Pruder, C. J. Langdon and D. E. Conklin), 
Rehoboth Beach, Delaware. World Mariculture Society, Special Publication No. 2, Louisiana State University, Baton Rouge, 1981, pp. 418.

19) D. E. Bordner, L. R. D'Abramo, and D.E. Conklin: J. World Mariculture Soc., 14, 11-24 (1983).

20) R. E. Condrey, J. G. Gosselink, and H. J. Bennett: Fish. Bull., 70, 1281-1292 (1972).

21) Y. Yokoe, and I. Yasumasu: Comp. Biochem. Physiol., 13, 323-338 (1964).

22) M. A. Hood, and S. P. Meyers: Proc. Gulf and Caribbean Fish. Inst., 26, 81-92 (1974).

23) M. A. Hood, and S. P. Meyers: J. Ocean. Soc. Japan, 33, 328-334 (1977).
24) P. H. Fair, A. R. Fortner, M. R. Millikin, and L. V. Sick: J. World Mariculture Soc., 11, 369381 (1980).

25) Y. Y. Ting: Bull. Taiwan. Fish. Res. Inst., No. 16,125 (1970)

26) R. H. Hackman: Aust. J. Biol. Sci., 13, 568-577 (1960).

27) D. L. Claybrook: in "Biology of Crustacea, Internal Anatomy and Physiological Regulation" (ed. by D. E. Bliss and L. H. Mantel). Academic Press, New York, 1983, pp. 163-214.

28) P. G. Lee, L. L. Smith, and A. L. Lawrence: Aquaculture, 42, 225-239 (1984). 